\title{
Efektifitas BLT Covid-19 di Desa Moyo Kecamatan Moyo Hilir Kabupaten Sumbawa (Studi Konstruksi Sosial Kemiskinan)
}

\author{
Imam Yuliadi ${ }^{1}$, Sumitro ${ }^{2}$ \\ ${ }^{1}$ Dosen Sosiologi FIS Institut IImu Sosial dan IImu Budaya Samawa Rea \\ Email: Imamyuliadi0@gmail.com \\ ${ }^{2}$ Dosen Sosiologi FIS Institut IImu Sosial dan IImu Budaya Samawa Rea \\ Email : sumitro765@gmail.com
}

\begin{abstract}
Pandemic conditions which certainly help the poor in earning a living, and BLT Covid 19 is one of the efforts to help ease the burden on the poor. The poverty referred to by the government is economic poverty, while in the field it is often found sociologically. For this reason, it is necessary to sort out to clarify which of the poor need to be dealt with economically and which of the poor need to be handled sociologically. In the study of sociology, it can be analyzed how a social phenomenon is constructed, so that it can be any factors that shape/influence a phenomenon. From these factors, actions can be taken to prevent social phenomena such as opportunistic actions born of a poor mentality. This research aims to; (1) the form of poverty that exists in Moyo Village, (2) This means that the impact of the Covid 19 BLT program on the construction of a poor mentality. The type of research in this research is descriptive qualitative. This research was conducted on the community who received the Covid 19 Direct Cash Assistance (BLT) in Moyo Village, Moyo Hilir District, Sumbawa Regency and the Moyo Village government where the BLT funds were taken from the Moyo Village APBDes. The research location will be in Moyo Village, Moyo Hilir District, Sumbawa Regency, West Nusa Tenggara Province. Data collection techniques using observation, interviews and documentation. The validity of the data using source triangulation. Data analysis technique with interactive model. From this research, several things can be obtained, namely; (1) the form of poverty that exists in Moyo Village, (2) the impact of the Covid 19 BLT program on the construction of a poor mentality. The forms of poverty in Moyo Village are structural poverty and subjective poverty. Where both are the impact of the Covid 19 Pandemic. Where structural poverty is a practical impact of the pandemic condition, while subjective poverty is a continued impact of the duration of the pandemic for the last 2 years. The Covid 19 BLT program also contributes to the construction of a poor mentality in society. The poor mentality is closely related to subjective poverty where the poor mentality is a core component of the subjective poverty construction.
\end{abstract}

Keywords : Effectiveness; BLT; Social Construction; Poverty.

Abstrak. Kondisi Pandemi yang berkepanjangan tentu menyulitkan masyarakat miskin dalam mencari nafkah, dan BLT Covid 19 merupakan salah satu usaha untuk membantu meringankan beban masyarakat miskin. Kemiskinan yang dimaksud oleh pemerintah adalah kemiskinan secara ekonomi, sedangkan dilapangan seringkali ditemukan kemiskinan secara sosiologis. Untuk itu perlu dilakukan pemilahan untuk memperjelas mana masyarakat miskin yang perlu ditangani secara ekonomi dan mana masyarakat miskin yang perlu ditangani secara sosiologis. Dalam kajian sosiologi dapat dilakukan analisa bagaimana suatu fenomena sosial terkonstruksi, sehingga dapat dijabarkan faktor-faktor apa saja yang membentuk/mempengaruhi sebuah fenomena. Dari faktor-faktor yang dijabarkan bisa diambil tindakan untuk mencegah terbentuknya fenomenafenomena sosial semacam tindakan-tindakan oportunis yang lahir dari mentalitas miskin. Penelitian ini bertujuan untuk; (1) Menjelaskan bentuk kemiskinan yang ada di Desa Moyo, (2) Menjelaskan dampak program BLT Covid 19 terhadap terkonstruksinya mentalitas miskin. Jenis Penelitian dalam penelitian ini adalah Deskriptif kualitatif. Penelitian ini dilakukan terhadap masyarakat penerima Bantuan Langsung Tunai (BLT) Covid 19 di Desa Moyo Kecamatan Moyo Hilir Kabupaten Sumbawa dan pemerintah Desa Moyo dimana Dana BLT ini diambil dari APBDes Desa Moyo. Lokasi penelitian akan berada di Desa Moyo kecamatan Moyo 
Hilir Kabupaten Sumbawa Propinsi Nusa Tenggara Barat. Teknik pengumpulan data menggunakan observasi, wawancara dan dokumentasi. Keabsahan data menggunakan triangulasi sumber. Teknik analisis data dengan interactive model. Dari penelitian ini bisa didapatkan beberapa hal yaitu; (1) bentuk kemiskinan yang ada di Desa Moyo, (2) dampak program BLT Covid 19 terhadap terkonstruksinya mentalitas miskin. Bentuk kemiskinan yang ada di Desa Moyo adalah kemiskinan struktural dan kemiskinan subjektif. Dimana keduanya merupakan dampak dari Pandemi Covid 19. Dimana kemiskinan struktural merupakan dampak praktis dari kondisi pandemi, sedangkan kemiskinan subjektif merupakan dampak lanjutan dari berlangsung lamanya pandemi selama 2 tahun terakhir. Program BLT Covid 19 juga berkontribusi terhadap terkonstruksinya mentalitas miskin dalam masyarakat. Mentalitas miskin erat kaitannya dengan kemiskinan subjektif dimana mentalitas miskin merupakan kompenen inti dari konstruksi kemiskinan subjektif.

Kata kunci: Efektifitas; BLT; Konstruksi Sosial; Kemiskinan.

\section{PENDAHULUAN}

Tahun 2020 adalah tahun dimana negara diuji dengan berbagai masalah, dari masalah di tingkat lokal, nasional maupun masalah kelas dunia. Salah satu masalah yang hingga kini masih kita rasakan adalah Corona Virus Disease 2019 (Covid 19). Pandemi Covid 19 memunculkan berbagai masalah di Indonesia, dari masalah kesehatan, instabilitas politik, pendidikan hingga masalah sosial ekonomi masyarakat. Untuk menanggulangi dampak sosial ekonomi yang terjadi pemerintah memberikan Bantuan Langsung Tunai (BLT) untuk meningkatkan daya beli masyarakat yang menurun akibat kebijakan karantina. Kebijakan karantina diambil pemerintah untuk menghambat atau mengatasi penyebaran virus melalui human-to-human transmission.

Kabupaten Sumbawa sebagaimana berbagai daerah lain di Indonesia juga mengalami hal yang sama, terkena dampak dari penyebaran virus ini. Kabupaten Sumawa merupakan salah satu dari beberapa wilayah yang pertama kali ditemukan kasus Covid 19 di Nusa Tenggara Barat. Kondisi ini menyebabkan wilayah ini dilakukan karantina yang tentunya menghambat kegiatan ekonomi masyarakat. Untuk menghadapi permasalahan sosial ekonomi tersebut maka pemerintah Desa setempat mengeluarkan dana BLT Covid 19 sesuai dengan aturan menteri keuangan anggaran yang diberikan adalah Rp. 600.000,- / Keluarga Penerima Manfaat/bulan selama 3 Bulan (April sampai Juni 2019). Namun bantuan tersebut dibatasi, masyarakat yang sudah menerima bantuan PKH, Kartu Sembako, dan Kartu Pra Kerja tidak diperkenankan menerima BLT Covid 19. Hal tersebut mendorong terjadinya perdebatan dikalangan masyarakat dimana data masyarakat miskin dari Kemensos sebagian besar sudah masuk dalam berbagai bantuan lain. Masyarakat yang merasa miskin menuntut bantuan serupa karena memang kondisi karantina menghambat mereka dalam mencari nafkah.

Ditinjau dari sudut pandang sosiologi kemiskinan, pengakuan seorang individu yang melabeli dirinya miskin merupakan bentuk dari mentalitas miskin atau kemiskinan secara sosiologis. Penerima bantuan langsung tunai Covid 19 membutuhkan label miskin, yang pendataannya dilakukan oleh pemerintah desa setempat. Masyarakat Sumbawa terkenal dengan nilai-nilai harga diri yang tinggi, dimana masyarakat Sumbawa enggan dianggap lemah atau miskin. Namun seiring dengan masuknya pengaruh globalisasi dan modernisasi, nilai nilai materialism mulai berkembang dalam masyarakat. Masuknya nilai nilai materialisme dalam masyarakat sejatinya diimbangi dengan menyiapkan mental masyarakat, sehingga pengaruh buruk tersebut tidak berkembang menjadi tindakan - tindakan oportunis.

Kondisi Pandemi yang berkepanjangan tentu menyulitkan masyarakat miskin dalam mencari nafkah, dan BLT Covid 19 merupakan salah satu usaha untuk membantu meringankan beban masyarakat miskin. Kemiskinan yang dimaksud oleh pemerintah adalah kemiskinan secara ekonomi, sedangkan dilapangan seringkali ditemukan kemiskinan secara sosiologis. Untuk itu perlu dilakukan pemilahan untuk memperjelas mana masyarakat miskin yang perlu ditangani secara ekonomi dan mana masyarakat miskin yang perlu ditangani secara sosiologis. Dalam kajian sosiologi dapat dilakukan analisa bagaimana suatu fenomena sosial terkonstruksi, sehingga dapat dijabarkan faktorfaktor apa saja yang membentuk/mempengaruhi sebuah fenomena. 


\section{METODE PENELITIAN}

Jenis penelitian yang digunakan dalam penelitian ini adalah penelitian deskriptif kualitatif. Menurut Bogdan dan Taylor, metodologi kualitatif adalah prosedur penelitian yang menghasilkan data deskriptif berupa kata-kata tertulis dari orang-orang dan perilaku yang dapat diamati (Moleong, 2002:3). Metode kualitatif dapat digunakan untuk mempelajari, membuka dan mengerti apa yang terjadi di belakang setiap fenomena yang baru sedikit diketahui. Penelitian ini menggambarkan konstruksi sosial kemiskinan (mentalitas miskin) di salah satu desa di Kabupaten Sumbawa yang melaksanakan program BLT Covid 19, sehingga bisa dianalisa lebih lanjut efektivitas program tersebut. Adapun Lokasi dan Subyek Penelitian ini dilakukan terhadap masyarakat penerima Bantuan Langsung Tunai (BLT) Covid 19 di Desa Moyo Kecamatan Moyo Hilir Kabupaten Sumbawa dan pemerintah Desa Moyo dimana Dana BLT ini diambil dari APBDes Desa Moyo. Lokasi penelitian akan berada di Desa Moyo kecamatan Moyo Hilir Kabupaten Sumbawa Propinsi Nusa Tenggara Barat. Teknik Pengumpulan Sampel terdiri dari : 1). Populasi, Populasi atau Universe adalah jumlah keseluruhan dari unit analisis (Slamet, 2006:40). Populasi merupakan jumlah tertentu dari individu yang akan diselidiki oleh peneliti. Populasi dalam penelitian ini adalah semua masyarakat di Desa Moyo di kecamatan Moyo Hilir Kabupaten Sumbawa; 2). Sampling, Sampel dalam penelitian ini bukan sesuatu yang mutlak. Artinya sampel yang akan diambil menyesuaikan dengan kebutuhan di lapangan. Dalam penelitian ini sampel berfungsi untuk menggali beragam informasi dan menemukan sejauh mungkin informasi penting. Teknik sampling yang digunakan adalah teknik Purposive Sampling. Sampel diambil dari 3 kelompok informan yaitu aparat desa sebagai pihak pemerintah desa, petugas penyalur BLT, dan penerima BLT.

Tabel Teknik Sampling

\begin{tabular}{|l|c|}
\hline Kriteria Sampling & Sampel \\
\hline Aparat Desa & 2 orang \\
\hline Petugas Penyalur BLT & 2 orang \\
\hline Masyarakat Penerima BLT & 4 orang \\
\hline Masyarakat tidak menerima BLT & 4 Orang \\
\hline Jumlah & 12 Orang \\
\hline
\end{tabular}

Adapun Teknik pengumpulan data yang dilakukan memanfaatkan beberapa media, diantaranya adsalah : 1). Observasi berupa pengamatan berkala terhadap aparat Desa, petugas penyalur BLT dan Masyarakat penerima BLT terkait program BLT Desa; 2). Wawancara (Interview) dengan pedoman wawancara dan catatan penelitian; 3). Dokumentasi menggunakan kamera dan Recorder Handphone, serta foto copy dokumen-dokumen pendukung dari pemerintah desa.

Dalam penelitian ini menggunakan teknik triangulasi dalam mencapai validitas data. Teknik triangulasi adalah teknik penarikan keabsahan data dengan memanfaatkan penggunaan sesuatu yang lain di luar data itu untuk keperluan penyelesaian atau sebagai pembanding terhadap data yang sudah ada. Dimana dalam penelitian ini menggunakan triangulasi sumber. Artinya membandingkan dan mengecek kembali derajat kepercayaan suatu sumber informasi yang diperoleh melalui waktu dan alat yang berbeda dalam metode kualitatif. Trianggulasi sumber dalam penelitian ini diambil dari dua sumber, antara lain: antara sesama penerima BLT dan perbandingan antara perspektif penerima BLT dan yang tidak menerima BLT. Sesuai dengan teknik pengumpulan data tersebut maka analisanya berkembang dan berjalan serta berlangsung proses di saat pengumpulan data dilakukan. Peneliti bekerja dengan data atau dengan teknik analisa data interactive of analysis yang mempunyai 
tahap-tahap sebagai berikut : a. Pengumpulan Data (Data Collection); b. Reduksi Data (Data Reduction); c. Penyajian Data (Data Display) Penarikan Kesimpulan (Conclusions); Melakukan penyimpulan terkait konstruksi mentalitas miskin di desa Moyo berpengaruh terhadap tidak efektifnya penetapan kriteria penerima dan penyaluran BLT.

Dari teknik analisa Data Interactive Model Of Analysis di atas dapat digambarkan dalam sebuah bagan seperti dibawah ini :

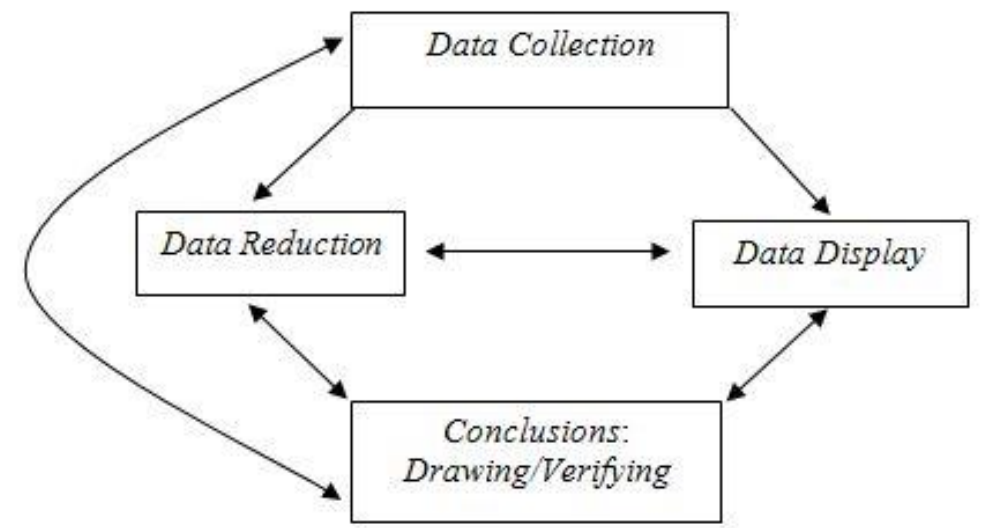

Bagan 2. Komponen dalam Analis Data (Interactive Model)

Sumber: (Sugiono, 2011:247)

\section{HASIL PENELITIAN DAN PEMBAHASAN}

\section{A. Bantuan Langsung Tunai}

Istilah Bantuan Langsung Tunai (BLT) digunakan untuk merujuk pada pemberian uang tunai oleh pemerintah kepada masyarakat miskin dengan berbagai tujuan. Era pemerintahan Presiden SBY, BLT digunakan untuk mengendalikan ekonomi masyarakat sebagai dampak kenaikan harga BBM masa itu. Periode Presiden Joko Widodo kebijakan serupa dilakukan dimasa awal pemerintahannya juga untuk menanggulangi pengurangan subsidi BBM. Dan saat ini di era pandemi dilakukan kebijakan serupa yaitu BLT dalam berbagai bentuk dan berbagai sumber. Ada BLT yang disalurkan lewat beberapa bank baik swasta maupun bank negara seperti Bantuan Produktif Usaha Mikro (BPUM) oleh kementerian UMKM dan Bantuan Subsidi Upah (BSU) yang merupakan BLT untuk guru honorer. Ada juga yang disalurkan lewat pemerintah desa yang disebut BLT Desa.

Berdasarkan pengumuman kementerian keuangan tahun 2020 BLT Desa dianggarkan langsung oleh desa maksimal $35 \%$ dari dana desa atau lebih dari 35\% dana desa dengan persetujuan pemerintah kabupaten/kota. Pendataan calon penerima BLT Desa dilakukan oleh kepala desa/ Tim relawan desa dengan mempertimbangkan Data Terpadu Kesejahteraan Sosial (DTKS) dari kemensos. Kriteria penerima BLT desa antara lain; keluarga miskin yang bukan penerima PKH, Kartu Sembako, dan Kartu Pra Kerja. Pemberian BLT Desa kepada masyarakat bertujuan mendongkrak daya beli masyarakat karena penghasilannya berkurang akibat pandemi. Dimana pandemi berdampak pada terbatasnya kegiatan ekonomi masyarakat akibat proses karantina dan berbagai protokol kesehatan lain.

\section{B. Bentuk Kemiskinan Yang Ada di Desa Moyo}

Kemiskinan adalah suatu keadaan yang terjadi pada seseorang dengan kondisi tidak sanggup memelihara dirinya sendiri sesuai dengan taraf kehidupan dalam kelompok sosial, selain itu juga kemiskinan dianggap tidak mampu memanfaatkan tenaga mental ataupun fisiknya dalam pergaluan dalam kelompok masyarakat. Diantara berbagai jenis kemiskinan yang ada, miskin secara material dan mentalitas miskin selalu memiliki hubungan timbal balik yang khas dalam kajian sosiologi ekonomi. Demikian pula pada kasus bantuan langsung tunai dimasa pandemi. Disatu sisi BLT dapat 
membantu masyarakat miskin secara material, namun dalam waktu lama dimana pandemi covid 19 berlangsung bertahun-tahun. BLT justru memupuk mentalitas miskin dalam masyarakat. Dimana masyarakat yang terbentuk mentalitas miskinnya akan selalu merasa kekurangan materi meski secara nominal sudah tidak bisa disebut miskin. Pada masyarakat desa Moyo yang terdampak pandemi covid 19 ditemukan dua jenis kemiskinan, yang pertama kemiskinan struktural dan kedua kemiskinan subjektf.

\section{Kemiskinan Struktural}

Kemiskinan struktural adalah kondisi kemiskinan yang terjadi pada masyarakat untuk menghubungkan antara sumber daya dengan sektor struktural masyarakat. Struktur sosial ini adalah sistem sosial yang memberikan peluang bagi masyarakat untuk mendapatkan taraf hidup lebih baik. Sebagai dampak dari pandemi Covid 19 pada 2020 silam, masyarakat desa moyo terpaksa mengalami lockdown yang mengakibatkan mereka tdak dapat melakukan aktifitas ekonomi secara normal. Kebijakan lockdown menyebabkan masyarakat lebih banyak beraktifitas di rumah, sedangkan mayoritas masyarakat Desa moyo berprofesi sebagai petani dan pedagang.

Dua profesi tersebut membutuhkan banyak waktu di luar rumah. Praktis pada masa lockdown sekitar kurang lebih 1 bulan pendapatan mereka berkurang. Beberapa dari mereka yang berprofesi sebagai petani disela-sela kegiatan bertani, mereka juga bekerja serabutan sebagai buruh bangunan. Disaat masa lockdown mereka yang bekerja sebagai buruh harian terpaksa tidak bekerja. Karena orang yang mempekerjakan mereka meminimalisir pengeluaran dengan mengurangi pekerja, ada pula yang pekerjaan bangunannya tertunda karena pemilik bangunan mengalami masalah ekonomi saat pandemi. Ada pula yang pekerjaan bangunan yang terhenti akibat lingkungan tempat kerja mereka di karantina. Berbagai kendala dalam kegiatan perekonomian tersebut membuat masyarakat dengan tingkat perekonomiannya rendah terpaksa mengutang selama masa lockdown dan beberapa bulan setelahnya sebagai imbas dari mandeknya berbagai kegiatan ekonomi sesaat pada masa pandemi.

2. Kemiskinan Subjektif

Selain kemiskinan struktural yang telah dibahas sebelumnya. Selama masa pandemi covid 19 di desa Moyo juga terjadi kemiskinan subjektif. Kemiskinan subjektif adalah kondisi kemiskinan yang dialami masyarakat berdasarkan pada hasil pemikirannya sendiri. Seseorang tersebut cenderung ingin mengatakan miskin karena kebutuhan serta keinginannya tidak terpenuhi secara cukup.

Beberapa informan yang tidak mendapatkan BLT mengidentifikasi diri mereka sebagai masyarakat miskin yang menurut mereka berhak mendapatkan BLT. Namun dari observasi yang dilakukan yang bersangkutan tidak bisa dikategorikan sebagai masyarakat miskin. Informan bekerja sebagai pedagang, yang meskipun terdampak covid 19 namun dilihat dari pendapatannya perhari relative masih bisa survive di tengah kondisi pandemi.

\section{Dampak Program BLT Covid 19 Terhadap Terkonstruksinya Mentalitas Miskin}

Pendekatan kualitatif dirasa tepat dalam penelitian ini dengan pertimbangan karena penelitian ini bertujuan untuk, pertama, mengungkapkan makna dari suatu tindakan atau suatu yang berada dibalik tindakan seseorang. Penelitian kualitatif lebih menekankan pemahaman "hakikat" realitas yang terbentuk secara sosial, terutama dalam menjawab pertanyaaan: bagaimana pengalaman sosial dibentuk dan diberi makna. Hal ini terutama didasari oleh asumsi bahwa manusia merupakan animal symbolicum yang mencari makna dalam hidupnya (Berger dan Luckman, 1990: 66). Kedua, penelitian kualitatif memberikan peluang untuk mengungkapkan secara mendalam tentang orientasi nilai apa 
yang menjadi pijakan dalam bertindak dari individu dalam lingkungan kulturalnya. Ketiga, penelitian tentang identitas etnik sangat tepat menggunakan penelitian kualitatif oleh karena yang diteliti adalah fenomena yang berada didalam individu bukan yang ada pada bagian luarnya saja. Keempat, bahwa untuk memahami fenomena identitas etnik sangat dibutuhkan suatu upaya untuk meraih suatu native's point of view, yaitu pandangan aktor (Suyanto, 2011: 227). Suatu proses pemaknaan yang dilakukan oleh setiap individual terhadap lingkungan dan aspek diluar dirinya yang terdiri dari proses eksternalisasi, internalsasi dan objektifikasi. Eksternalisasi adalah penyesuaian diri dengan dunia sosiokultural sebagai produk manusia, obyektivasi adalah interaksi sosial dalam dunia intersubjektif yang dilembagakan atau mengalami proses institusionalisasi, dan internalisasi adalah individu mengidentifikasi diri ditengah lembaga-lembaga sosial dimana individu tersebut menjadi anggotanya.

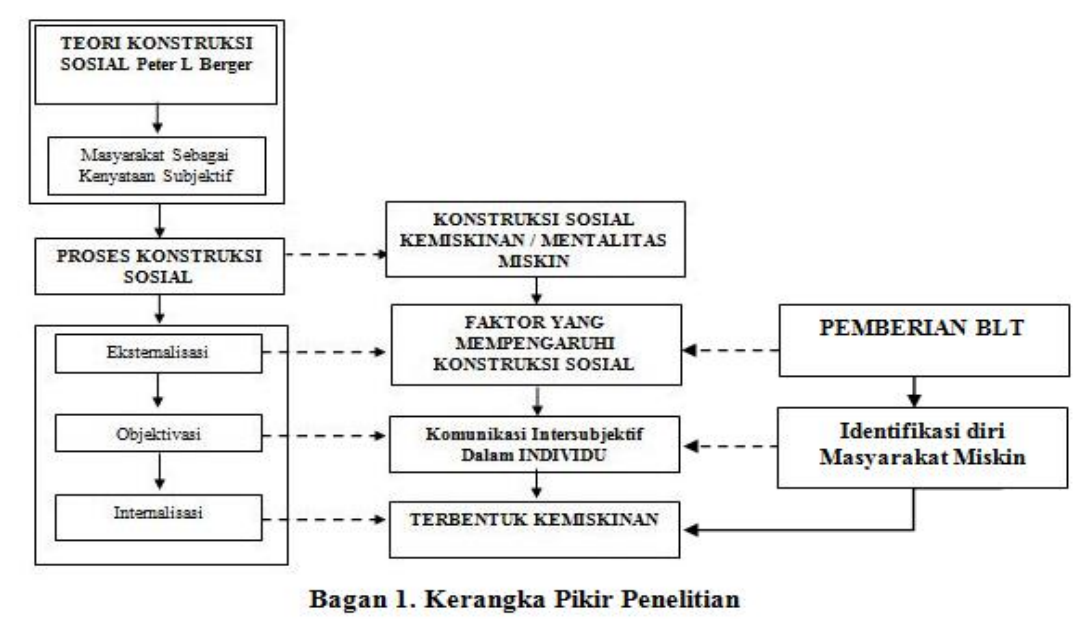

Istilah konstruksi sosial atas realitas (social construction of reality) didefinisikan sebagai proses sosial melalui tindakan dan interaksi dimana individu menciptakan secara terus menerus suatu realitas yang dimiliki dan dialami bersama secara subjektif (Poloma, 2004: 301). Pemberian BLT dalam waktu lama akan mengkonstruksi masyarakat dalam bingkai kemiskinan. Penerima BLT adalah masyarakat yang terindikasi sebagai masyarakat miskin, dimana masyarakat tersebut merupakan objek dari bantuan. Pemerintah sebagai subjek pemberi bantuan mengidentifikasi masyarakat tersebut sebagai masyarakat miskin. Dalam proses lama yang disebut oleh Berger sebagai subjektivasi masyarakat tersebut akan mengidentifikasi diri sebagai masyarakat miskin yang berhak menerima BLT. Sehingga masyarakat kemiskinan yang awalnya merupakan identifikasi sementara akibat kondisi pandemi (untuk penyaluran BLT), berubah menjadi identifikasi permanen dimana masyarakat penerima BLT melabeli diri sebagai masyarakat miskin. Lebih jauh lagi seseorang dengan mentalitas miskin akan mengambil langkah-langkah oportunis demi mendapatkan bantuan langsung tunai.

\section{KESIMPULAN}

Dari penelitian ini bisa didapatkan beberapa hal yaitu; (1) Bentuk kemiskinan yang ada di Desa Moyo, (2) Dampak program BLT Covid 19 terhadap terkonstruksinya mentalitas miskin. Bentuk kemiskinan yang ada di Desa Moyo adalah kemiskinan struktural dan kemiskinan subjektif. Dimana keduanya merupakan dampak dari Pandemi Covid 19. Dimana kemiskinan struktural merupakan dampak praktis dari kondisi pandemi, sedangkan kemiskinan subjektif merupakan dampak lanjutan dari berlangsung lamanya pandemi selama 2 tahun terakhir. Program BLT Covid 19 juga berkontribusi terhadap terkonstruksinya mentalitas miskin dalam masyarakat. Mentalitas miskin erat kaitannya dengan kemiskinan subjektif dimana mentalitas miskin merupakan kompenen inti dari konstruksi kemiskinan subjektif. Kondisi seperti ini terbentuk/terkonstruksi dalam waktu yang relative lama namun jikalau sudah terbentuk akan sulit untuk merubahnya/ memperbaiki mentalitas masyarakat. 


\section{DAFTAR PUSTAKA}

Adasasmita, Rahardjo., 2015. Analisis Kebijakan Publik. Yogyakarta: Graha Ilmu

Asnaneni, St., 2013. Perubahan Perilaku Sosial - Budaya Studi Pada Masyarakat Penerima Bantuan Langsung Tunai di Kelurahan Batangkaluku Kabupaten Gowa: Penelitian Dosen Pemula

Ikbar, Yanuar., 2012. Metode Penelitian Sosial Kualitatif. Bandung. Rafika Aditama

Meleong, Lexy. 2002. Metode Penelitian Kualitatif . Bandung: Remaja Rosda Karya.

Narwoko, J Dwi dan Suyanto, Bagong. 2011. Sosiologi; Teks, Pengantar dan Terapan. Jakarta: Prenada Media Grup.

Poloma, Margaret M. 2004. Sosiologi Kontemporer. Jakarta ; PT Rajagrafindo Persada.

Ritzer, George. 2012. Teori Sosiologi dari Sosiologi Klasik Sampai Perkembangan Terakhir Postmodern. Yogyakarta: Pustaka Pelajar

Setiadi, Elly M dan Kolip, Usman. 2011. Pengantar Sosiologi, Pemahaman Fakta Dan Gejala Permasalahan Sosial: Teori, Aplikasi, Dan Pemecahannya. Jakarta: Kencana

Slamet. Y. 2006. Metode Penelitian Sosial. Surakarta: UNS Press

Soekanto, Soerjono. 2012. Sosiologi Suatu Pengantar. Jakarta: Rajawali Pers

Sugiyono. 2011. Metode Penelitian Kuantitatif, Kualitatif, Dan R \& D. Bandung: Alfabeta

Susilo, Rahmad. K. Dwi. 2008. 20 Tokoh Sosiologi Modern: Biografi Para Peletak Sosiologi Modern. Jogjakarta: Ar-Ruzz Media

\section{UCAPAN TERIMA KASIH :}

Pada kesempatan ini tidak lupa kami ucapkan terima kasih kepada Kementerian Pendidikan dan Kebudayaan (Kemendikbud) Lembaga Layanan Pendidikan Tinggi Wilayah VIII (Bali - Nusa Tenggara) (LLDIKTI-VIII) selaku pemberi dana penelitian Sehingga penelitian ini bisa terlaksana sesuai dengan waktu yang ditetapkan. 